\title{
METAMORPHOSIS OF PUBLIC SPACES IN HUNGARY OR THE QUESTION OF CONTEXT WITHIN THE PUBLIC SPACES OF THE COMMUNIST AND POST-COMMUNIST PERIOD
}

\author{
Kornelia Kissfazekas \\ Department of Urban Planning and Design, Faculty of Architecture, Budapest University of \\ Technology and Economics, Müegyetem rkp. 3. K. II/93, 1111 Budapest, Hungary \\ E-mails:kissfazekas@gmail.com; kissfazekas@urb.bme.hu
}

Received 11 June 2013; accepted 16 July 2013

\begin{abstract}
The design of successful public spaces is not merely a simple stylistic problem, but also a reflection on the social circumstances of a certain era, an architectural answer to the demands of society (Shields 1986). By following the continuous change in public spaces, we can observe a particular slice of history. This study is an investigation of the changing roles of two very different types of public spaces common in Hungary: the new urban squares of the ' 50 s and the centres built in the '70s for public institutions. The study accomplishes this primarily by analysing them within their different contexts. The conclusion of this study is that public squares built in the communist period can meet contemporary space use demands in different ways. However these square types' problems have great differences in scale and nature, during their renewals the deep knowledge of their history is essential. This is the precondition to creation public spaces that are intimately linked to the venue (and its spirit and history), even if we use fashinable designing tools.
\end{abstract}

Keywords: communist and post-communist period, socialist-realist-style, context, identity, urban spaces, network of public spaces built for public buildings, space use.

Reference to this paper should be made as follows: Kissfazekas, K. 2013. Metamorphosis of public spaces in Hungary or the question of context within the public spaces of the communist and post-communist period, Journal of Architecture and Urbanism 37(3): 182-193.

\section{Introduction}

"The city-center is the core that determines the city. It is the center of the inhabitants' political life... Political demonstrations, precessions and festivals take place in the center' public spaces. The marches, the political demonstrators and the speed with they move provide the scale for the politically determined city center." ${ }^{1}$

These were the words of Dr Lothar Bolz, the German Democratic Republic's Minister of Reconstruction in 1950 , concerning the government-approved basic principles of town-planning.

\footnotetext{
1 Bolz, L. 1952. The basic principles of city planning, Településtudományi Közlemények (Journal of Urbanism) 1:115-134.
}

His observations were shaped by his study-tour to the Soviet Union. Soon after their publication in East Germany, his comments became well known in Hungary too, where they were published in the first issue of 'Településtudományi Közlemények' (Journal of Urbanism ${ }^{2}$ ) and could be considered as harbingers of a new era. So the importance of public spaces and especially the role of city centers was widely acknowledged and emphasized in Hungary ever since the establishment of communism there (French, Hamilton 1979) This is especially true of the newly built public spaces.

\footnotetext{
2 One of the best journal of urbanism published in the state socialism in Hungary. Editor: Technical University of Budapest 1952-1973.
} 
The nearly 45 years of communism was a complex, constantly changing period. During this time the priorities of town planning changed significantly and the special attention initially paid to the role of public spaces eventually much slackened. In the fifties, during the beginning of the studied period, urban policy considerations were the determining factors behind urban design decisions, but in later decades this was overshadowed by vocational policy considerations. All these decisions, however, shared the characteristics of paying no attention to local conditions and historical precedents. As a result, there was no sense of continuity in any sense, not even in terms of urban design. (Kissfazekas 2008a, b).

So the relationship of new public spaces and architectural complexes to the genius loci is quite unique and has to be interpreted. In the several decades since their construction, these spaces and buildings not only became parts of history and its continuity, but they became integral - although unusual and contradictory - elements of genius loci, the spirit of the place (Markevičienè 2012). Has the original creative spirit that shaped these spaces been preserved, or - if it hasn't - what transformed them into something else and - most importantly what is the result of this transformation?

The question of identity and context is an important aspect of historical continuity and its relationship to the genius loci (McFarlane 2011). Context, which has long been accepted and used as a key concept in describing urban design, ensures not only the text's inner structure and coherence, but also the factors that go beyond the text (Kwan 2012). These factors include the web of relationships connecting the physical, social, cultural, and historical environment. It is especially important to consider this where - the products of urban design conceal a complicated set of relationships. Analysing context in relation to the events of urban construction must include not only the problems and inter-relationships of space and volume, but an examination of their historical, social and political background as well (Johnson, Glover 2013; Soja 1985).

The present study wishes to analyse how the urban spaces created during the years of communism in Hungary have been transformed in the course of time and how their context has changed. It intends to demonstrate how the role of public spaces in cities changed in the period following the Second World War and to describe the public expectations as to their design and use. The study also wishes to describe two typical types of the period's newly created public spaces, but its goals don't include an analysis of the changed use and alteration of preexisting historical spaces during communism.
Of the various possible aspects of the subject, our study primarily focuses on the changes in identity and context. It presents two basic space types that became standard elements in Hungarian town-planning.

We selected these two types of public spaces primarily because they are so common and imitated in Hungary. Their analysis not only enables us to present their spatial and architectural aspects, but also to get acquainted with the period of communism and its changing ideas concerning urban policy and design.

These types demonstrate the changes in social and political expectations during the early 1950s (Kozmlnskl, Obloj 1991), expectations that were frequently subjected to demagoguery at the time. They also show how the modes of expression in urban design and architecture have evolved together with the urban content, design, and face of public spaces (Clark 2003). Finally, the examples document the way certain towns tried to find new forms and sometimes also new content in Hungary. By following this process, we can see how public spaces - sometimes consciously at other times inadvertently - possess such social content that clearly reflects the priorities, attitude and main paradigms of a given era.

Our presentation of the above-described aspects is based on two of the basic types of public spaces in Hungary:

- newly built main squares/ representative squares from the 1950s (1960s);

- modern sequences of public spaces in the new complexes of public institutions and city centers built in the 1970s (1960s).

An examination and sorting out of these types is justified not only because they highlight different aspects of the relationship between communism and urban design, but also because these configurations of public space responded differently to the changed circumstances of the post-communist period. Their spatial and architectural features, their role and situation within the city, and their contexts were substantially different already when they were new, so it is no coincidence that their response to trying to find a role and form differed too.

\section{Two subperiod - two space types}

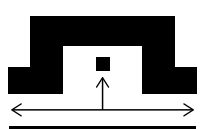

'The marching pedestrian and his/her speed', or the main square for official functions (Lefebvre 1991)

During the beginning of communism in the early 1950s, the formulation of principles and the exact expression of expectations were central tasks in all areas of everyday life 
(Kozmlnskl, Obloj 1991). Building towns became not only a post-war need but a political question as well. Hungary wanted to become a land of iron and steel, and this required a forced rate of development. Planning the industrial transformation of cities has already been going on, and the regime could not allow this to happen without proper political content and message. Hungary followed the example of the great Soviet Union only to limited degree in the sense that it didn't build a large number of new industrial towns (Szirmai 1988, 1998).

The best known and most important such new industrial town was Sztálinváros (today: Dunaújváros), intended to be the foundation of the communist heavy industry in Hungary. Its planning was controlled not only by urban design considerations, but also by political expectations concerning its town center and main square that echoed basic ideas formulated by the Central Committee of the Communist Party ${ }^{3}$.

Construction of the 'first communist town' erected on agricultural land started in 1951; the events of its construction, the shaping of its town structure, the development of its first residential neighborhood units and more important public institutions happened mostly in fifties. By examining them, we can observe the various stages of the short-lived Hungarian socialist-realist-style architecture ${ }^{4}$ as well as the subsequent return to modernism (Ferkai 1992). While the city went through some changes in architectural styles, the design of city structure and urban planning featured

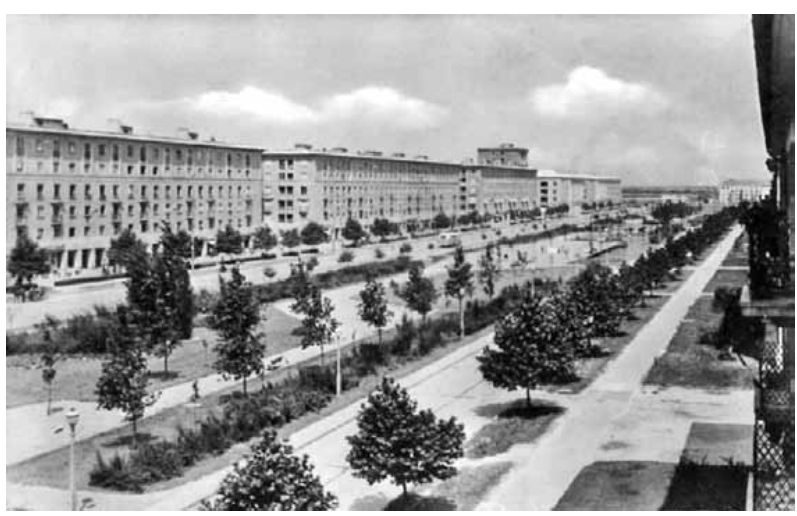

Fig. 1. Dunaújváros (formerly: Sztálinváros) - the wide Steelworks Street connected the factory entrance with the main square

\footnotetext{
3 The town center must be designed to be suitable for demonstrations and official festivities... The party headquarters, the main buildings of the town council, unions, and social organizations, the central house of culture, library, museum, and home for creative people should all be on the main square (Excerpt from the planning program of Sztálinváros).

4 Socialist realism was based on Marxist and Leninist ideas. Period of socialist realism lasted only a few years in Hungary: 1948-1955.
}

traditional 'classical' elements: a wide boulevard leading to the railway and another one to the factory, and at their crossing a main square that includes the most important municipal buildings (Figs 1,2).

Although the construction of this town, intended to be an example to follow, was based on careful prior planning, and the quality of its architecture was outstanding, it is a peculiar fact that there was an about 25 -year delay in developing its main square. (nowadays it's even not complete) In vain were there firm principles and detailed requirements laid out for the location and role of this square, the construction of the factory, residential neighbourhoods, and public buildings was deemed more urgent and it didn't leave sufficient resources for the central square. (Prakfalvi 2002; Prakfalvi, Szücs 2010)

Notwithstanding this, ever since the start of the town's construction several plans were prepared for its main square. These plans had the outstanding feature of a big, regularly shaped central square, suitable for political and social festivities, and surrounded by the most important public buildings, like the town-hall and the district headquarters of the Communist Party Committee. It was an axially symmetrical, regularly shaped main square marked, however, by an asymmetrically placed vertical element: a tower. (Barykina 2008) This latter feature became nearly ubiquitous in the plans of main squares during the fifties and sixties (Lefebvre 1991) (Figs 3-5).

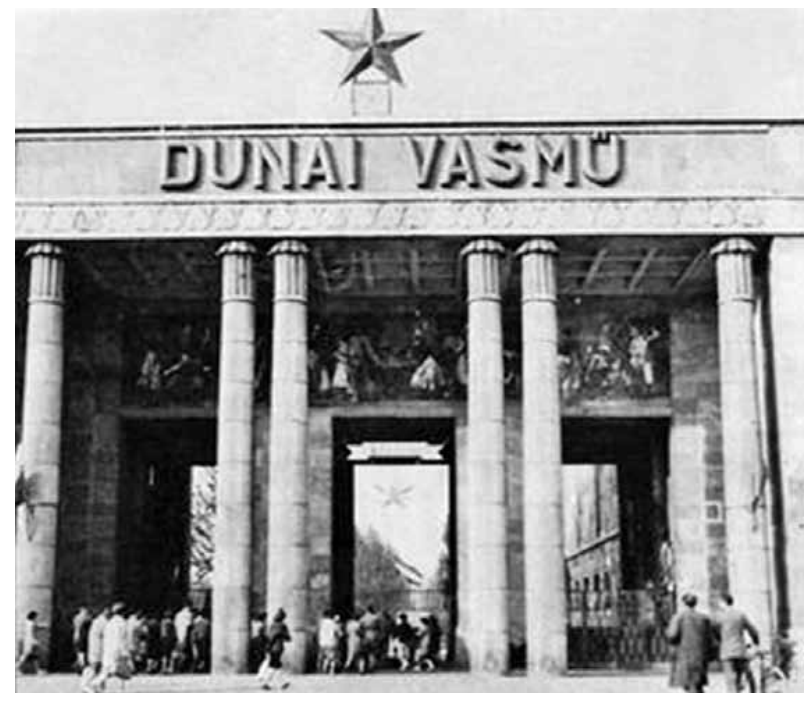

Fig. 2. Main entrance of the steelworks, a good example of the socialist-realist-style in Hungary 


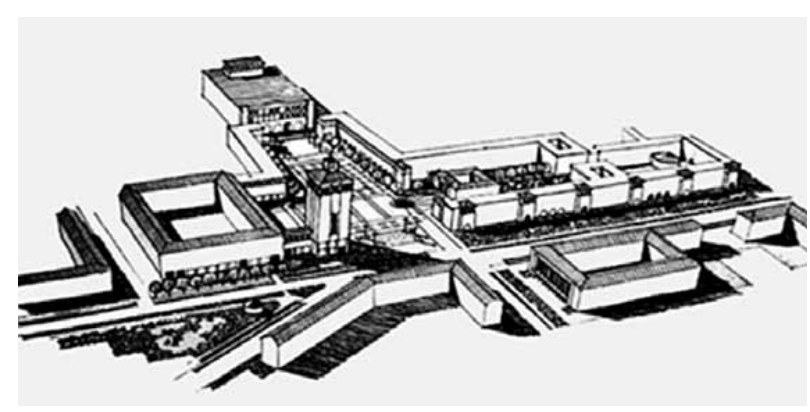

Fig. 3. One of the plans for the Sztálinváros (Dunaújváros) city center

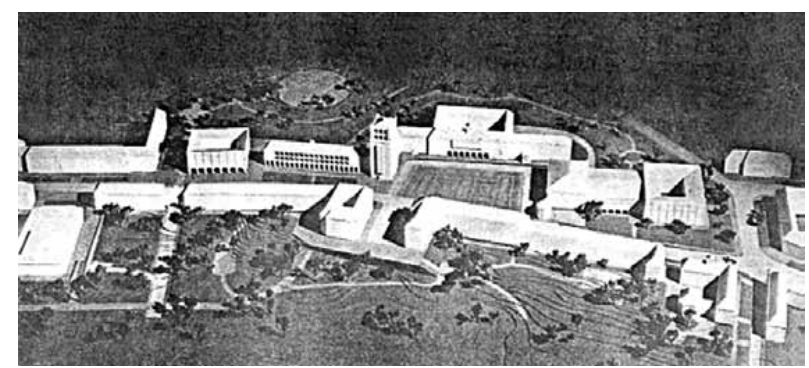

Fig. 4. The model of an other city center planned for Kazincbarcika

Due to the official nature of these squares, they frequently featured - typically for the period - monuments and statues of emblematic figures in their center, features that the inhabitants perceived as some kind of a visual code (Figs 6-8). One of the best-loved such statue was the figure of Lenin, standing on a high pedestal (Dobrenko, Naiman 2003; Cady 2009).

These centrally placed monuments and statues became obstacles to the free use of the whole square. But allowing unrestricted movement for the participants of festivities wasn't the primary function of these squares. They were festive squares that served as an urbanisti-

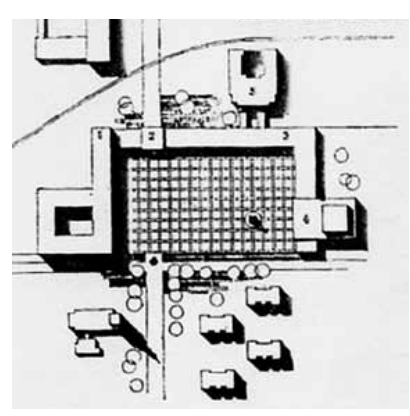

Fig. 5. Competition entry for the square in front of the Diósgyőr factory, one of the biggest Hungarian works of heavy industry. It features an asymmetrically placed vertical element near the entrance

cally, functionally, and ideologically important place, while allowing to lay wreaths at the monuments and hold commemorations.

The connection of the main square and the main avenue/main street was an essential consideration in locating the square within the town's spatial composition. At times its free-standing monuments served as axial closing elements at the end of main avenues, at other times the squares were adjacent to the avenue. This latter location enabled them to become a part of the bigger processions on the avenue, since during these political processions the people marching on the avenue could cast a grateful glance at the statue of one of their heroes or political leaders (Figs 6, 7).

This new component of urban structures was realized not only as the new main square of new towns, but also as new squares in historical towns. There too, the free-standing monumental statue was the essential element of the composition, serving as the visual end point of one of the town's axes, preferably of a historical axis (Fig. 8).

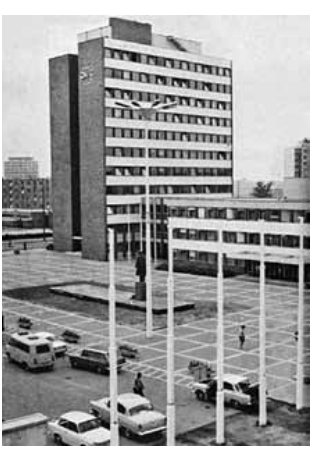

Fig. 6. The statue in the middle of the main square of Sztálinváros serves as a visual closing for the urban axis starting at the railway station

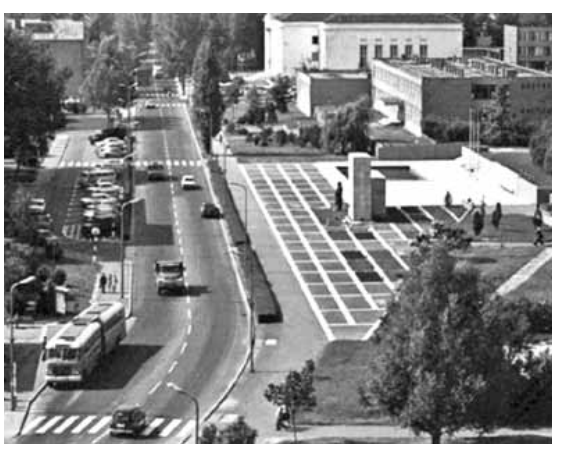

Fig. 7. Tatabánya new town; the square adjacent to the main axis with a statue in its centre

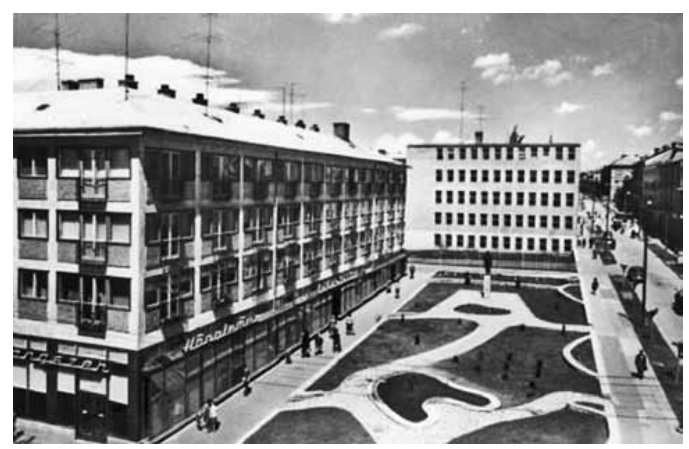

Fig. 8. A new, regularly shaped public square with a free standing sculpture on it, created in the ' 50 s in the historical town of Kaposvár 


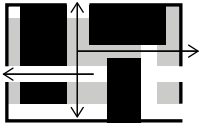

New modernism - new squares for public institutions (1960s) 1970s (Lefebvre 1991)

Already back in the ' 60 s and '70s another characteristic version of communist square type mentioned in the introduction appeared in the urban institutional centers. By that time the idea making of Hungary 'the country of iron and steel' became a thing of the past, (Kozmlnskl, Obloj 1991) and it was not no longer compulsory to apply strict political directives in urban architecture. New guidelines were given based not on demagogic political ideas, but on technocratic directives initiated by principles of the planning profession.

The manipulation of the regional activities of cities and the conscious influence of relationship between forces were important efforts in communism. New fields were occasionally emphasized; new cities of great industrial or military importance were absorbing attentions and got extra duties and priorities in the course of developing their network of institutions and services. But beside them the majority of historical towns could certainly save their original regional roles.

From the beginning of the 1960s, a recurring idea of the new National Settlement Network Development Plan was to make historical city centres suitable to fulfill ,modern' urban tasks in accordance with their centrally prescribed field of activities. Historical city centres were expected to 'fulfill new tasks, like the creation new and still not really revealed ways of communal life', but the spatial and physical potentials of existing historical towns were usually not suitable for that.

The reorganisation of city centres, the renewal of their public spaces and institutions capable to adopt a new way of communist life and new institutional model became the basic paradigm in the second half of the $60 \mathrm{~s}$. By that time historical centers were already in a very bad shape.

The '70s can be in all likelihood considered as the most active period of building city centre public institutions. However, the energy crisis of 1973-1974 had its influence on the construction industry and resulted in a policy of savings. Investment costs were strictly controlled by the Central Planning Board. A new directive was issued by the Ministry of Housing and Public Construction, aiming at giving priority to housing and at using available financial resources in a more efficient way. It also intended to prevent the building of expensive, extravagant city centres. Investment costs of planned buildings were controlled, and norms could be exceeded only if a 'special permission' was granted. Standardization was regulated, detailed regulations were issued on standard designs.
From the end of the 1960s prefabrication became dominant, whereas in the construction of public buildings strong priority was given to industrialised structures based on the principles of size-coordination.

The basic architectural principles and style have completely changed. Socialist realism in architecture and city planning applied rather conventional tools which were not strange to the planning and compositional principles of historical towns: axiality, symmetry, visuality. However at beginning of the 1960s, the basic principles of modernism returned.

Designers often tried to follow modern, contemporary ideas of urban designing, first of all the idea of monofunctionality, segregated traffic and multi-storey institutional centres. The new building complexes built in these years could not find their place and context with their historical environment (Figs 9-11).

The new institutional centres as high level services concentrated the most important modern service buildings and the main lines of social movements. The concentred presence of working masses was no longer directed by the compulsory social and political programmes and former organisations, but by the institutions of communist market economy increasingly opening room to people's demands for leisure and shopping. The new centres became urban nodes on the mental map (Smith 1996; Simmel 2005).

In some towns, the large-scale constructional works resulted a coherent composition, as a result of the demands of the bigger city centre development programmes of county seats and local ambitions'efforts to enlarge them.
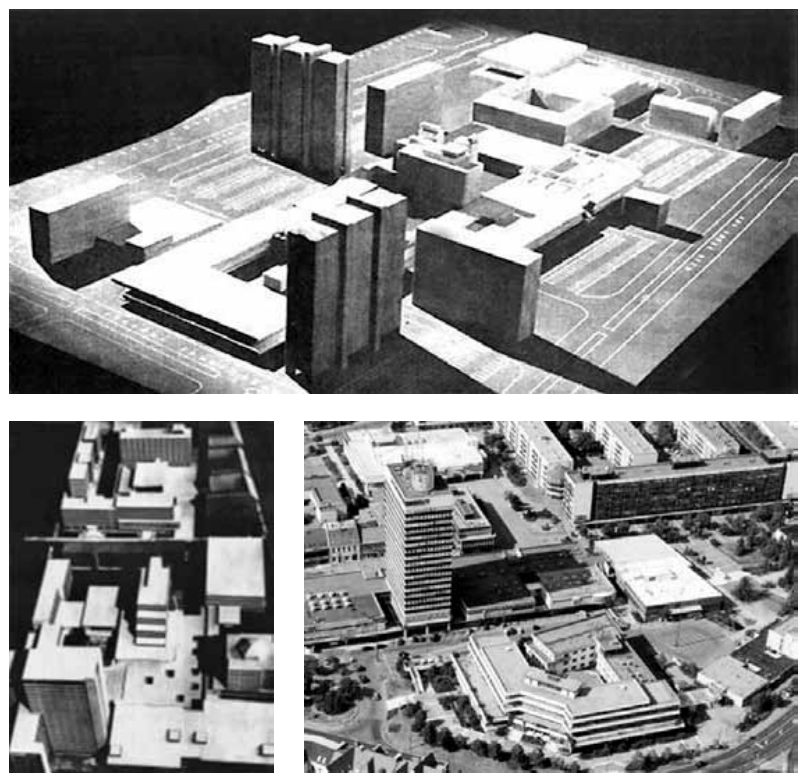

Figs 9-11. New centres of public institutions and services Szolnok, Pécs, Veszprém 
The city center of the central Hungarian town of Szolnok can serve as a good example for this. The development of the city was determined by the vicinity of Tisza river. As a result of its strategic position and its commercial and defensive role, the city can look back on a rich and stormy past. The continuous urban development was the result of the regulation of the river, the arrival of steam boats, the construction of railways, industrialisation and the appearance of the bourgeois citizens.

This urban development took place along the straight axis linking the train station and the bridge on the Tisza river. The most important public buildings were built along this main road and on the historical market square (Kossuth square) next to it.

After World War II, as a result of socialist industrialization, new industries without traditions appeared in the town. However, the special position of the city was not only attributable to its industrial role. After World War II Szolnok had an important strategic role, which was also underlined by a strong Russian military presence. During the 1960s the industrial and urban policy planned the doubling of the city's population.

At the same time, up to the beginning of the 1970s, the city had no centre 'worthy of its socialist development'. In 1972 the county party committee passed a resolution according to which for the 900th anniversary of the city's foundation and the 30th anniversary of its 'liberation' (1975), the town had to be made worthy of the momentum. 'Joining forces of the county and with the support of institutions of nation-wide competence' an enormous construction campaign was launched with ambitious plans to build public buildings. It was along this that the new institutional centre 'worthy' of the city's role and population size was erected in one urban block, with the city's most important representative public buildings (headquarters of the county and municipal party committee, polyclinic, cultural centre, department store, six-storied hotel, which looked small beside an 18-storied new office building planned as a visual accent). Buildings with commercial functions were planned along the long inner pedestrian routes, in between the accentuated high rise buildings.

The project was not completed, for financial reasons the planned deck-system had to be simplified, but even with this the centre could be inaugurated in the last minute, in 1974.

These types of city centre developments in accordance with their programmes and scales were beyond the needs of cities. They often became prestige investments forced by certain individuals, made on the site of a reconstructed urban block or on sites of some incorporated city blocks. In that cases these building complexes formed 'city islands' with sharpe division lines between squares and the urban fabric around them.

Their dimensions varied, their layouts determined by their own rules were organised with a reflection on each other and less so on their surroundings. Pedestrians were crossing the space between the building in a dynamic way. The traditional use of streets hasn't already been a determining factor, different shops, entrances opened on the interior of the urban block and not on the bordering streets. The main features of spaces in between became permeability and dynamism.

The urban square model examined does not posses typical communist characteristics, it rather followed the paradigms of modernism in urban design ('erasure and replacement')(Kipnis 1993). But it is an important element when studying the ways communism used space. Partly it was ingrained in urban architectural value orientations, partly it formed an example to be followed in erection new centres from the end of the 1960s. During their construction all the well-known urban principles were ignored: arrangement of individual building sites, city structure, layout system, city management. However, it needs to be pointed out that this type of square patterns and spatial structure almost lost theirs social base in the later decades. We will deal with the contemporary functions of public spaces later.

\section{Comprehensive evaluation and question of context}

The only common feature of the two square types mentioned above is that both became often used urban architectural and space structural elements in the one party system. One or the other, sometimes both are essentially present in the bigger Hungarian towns of todays, making their comparative analysis in this paper justified. However, their management and vitality show clear differences. Let's summarize them:

They were born in different sub-periods, but as time passed on, there have been basic ideological changes.

- Political and social impacts.

The square types mentioned in section 'The marching pedestrian and his/her speed', or the main square for official functions' came into use in the 1950s. Hungary's communist one-party system was well known for its demagogic and propagandistic ideas, which tried to strengthen people's political and social commitment with the help of urban design and architecture. However, by the 1960s this policy became less strict (country is over the 
Hungarian revolution of 1956 against Russians), its relation to urban architecture and to the demands of urban design have changed too.

We witness a stronger professional ambition for rational, normative way of thinking, free of ideology.

- Aspects of urban architecture.

In the middle of the 1950s socialist realist style became dominant, be it in the field of urban architecture axiality, space hierarchy, symmetry, or model of regular, closed squares encircled by buildings. There are only a few 'clearly' socialist realist buildings, most of them are rather characterised by a mixture of modernism, new modernism and socialist realism, but in the field of urban architecture certain compositional ideas of the period stayed on permanently. The idea of high rise building as accentuation of squares remained one of the basic element of new squares for more than 25 years.

Coming close to the " 70 th, the designing of space structures was no longer determined by political ideologies, but rather by aspects of urban architectural trends. New, up-to-date, internationally used principles of designing were adopted, they differed from the traditional streetsquare patterns of use. Informal routes offering free crossing possibilities within the urban blocks were considered as block structure.

One of the most important function of main squares built in the time of communist was to give room to the holding of guided communal programmes. Public squares had to satisfy the demands of state policy and urban policy, they were expected to be big enough for society-forming, organised and controlled mass demonstrations of communism.
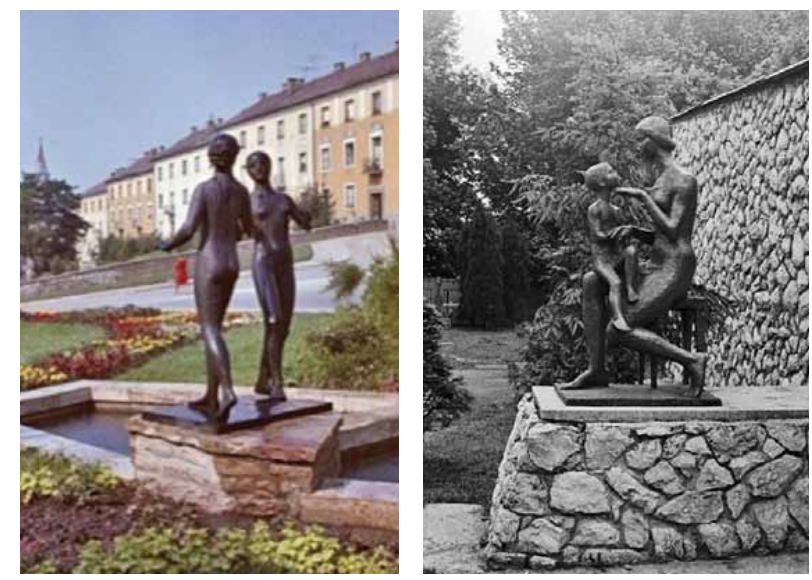

Figs 12,13 . Sculptures of different housing estates
With the weakening of communist ideology and centrally directed system, this communal attitude has slowly changed, giving room to adopting individual ways in using squares. In designing institutional centres emphasis was already given to satisfying costumers' needs through public space movements.

\section{- Planners' tools.}

The most remarkable and substantial element of public space design in the 1950s was the colorful and rich vocabulary of sophisticated artistic decorations. The signs of that ambitious design could be seen not only on the marked public spaces, but in the housing estates too, where in the interiors of urban blocks, (Figs 12,13) or in the surrounding of special building lots called "úszótelek" green areas provided a really pleasant microenvironment with their uniformal pattern language, toolbar and materials. The role of statues was similar to Kevin Lynch's elements of mental map serving as urban symbols and landmarks.

\section{Context of society and squares}

The above summary is very useful for studying contexts.

In the respect of evaluation of the two types of squares the ways of their different reactions to the social and environmental demands of the given period presented during their building are determinant.

The first type ('The marching pedestrian and his/ her speed', or the main square for official functions) was forced to comply with the demands of public space functions determined by the policy spectacularly. So its social context is rather inconsistent. Although it fulfilled a sort of social demand, this expectation was based on state controlled and artificially generated public space functions. Its space and urban context, first of all in the field of urban fabric and urban design (Kissfazekas 2010) developed in a more fortunate way. Naturally, it is difficult to define the urban structure context of new towns, because the traditional system is missing. But it is obvious that the spatial levels of the context mentioned above are good, because allocation of the public squares and their design were based on historical way of volume and space structuring with traditional scale of values. Main squares were placed in city centres, on ideal sites of the body of towns, their good and hierarchic connections to other urban elements were considered important during planning city structure, and traditional urban architectural ideas were followed in their design.

'Úszótelek': often used form of building lots of Hungarian housing estates. It contents the ground under the building and the surfaces of pavements around it. 
A compatibility of principles mentioned above with traditional urban environment can be seen in those cases, where new public spaces were erected in existing settlements (Figs 14-16). High-pitched buildings placed on street lines, forming closed facades were not strange for traditional Hungarian street-scape and space-volume scales.

The social context of the second presented square type ('New modernism - new squares for public institutions (1960s) 1970s') is completely different. Its birth was free of ideology and was rather determined by aspects of planning profession, with negligible social context. The primary cause of its emergence was not intention for form space, but rather to erect new building complexes. In spite of that, the role of spaces between buildings and public space network are still not negligable. They were considered not as 'additional elements', but in accordance with the basic ideas of modernism pushing for democratic and homogeneous space use, they formed an essential part of urban architectural conceptions.

The appearance of this square type raises serious doubts, not so much regarding questions of state so- cialism, but rather the relation of modernism to historicity. The location of new centres and public buildings and of new urban squares mobilizing new, important social forces were determined by practical aspects, like the rate of demolished buildings as compared to those newly built, the management of construction activities, the location of new housing estates, etc. Their position in the physical body of cities and their context with the historical centres are strongly disputable (MacIntyre, Ellaway, Cummins 2002). They were not seeking to look for a connection with city structures and historical squares. They didn't looked for structuring ideas and the logic of city structures, the continuity, the inspiring force of genius loci and context on the level of urban fabric either (Figs 17-19). The urban architectural toolbar applied was also strange to the historical scale of squares, especially regarding quality and size, as can be seen in new Hungarian city centres. As a consequence, its raison d'etre can be questioned on the level of urban design, too.

In spite of this, one must admit that in their use social impacts were quite considerable. Until the change of the political and economic regime, their walking streets
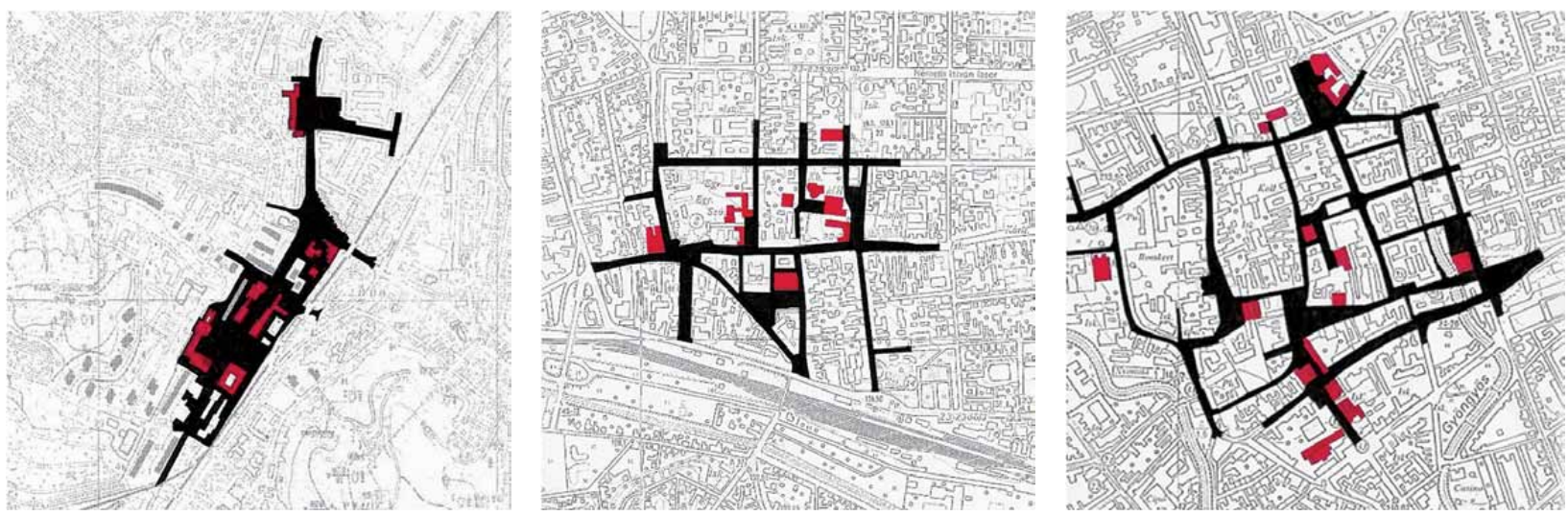

Figs 14-16. New square of new town - Salgótarján - with its regular squares joinede to the main road; New square cut in the historical urban fabric - Kaposvár; Szombathely (Kissfazekas 2010)
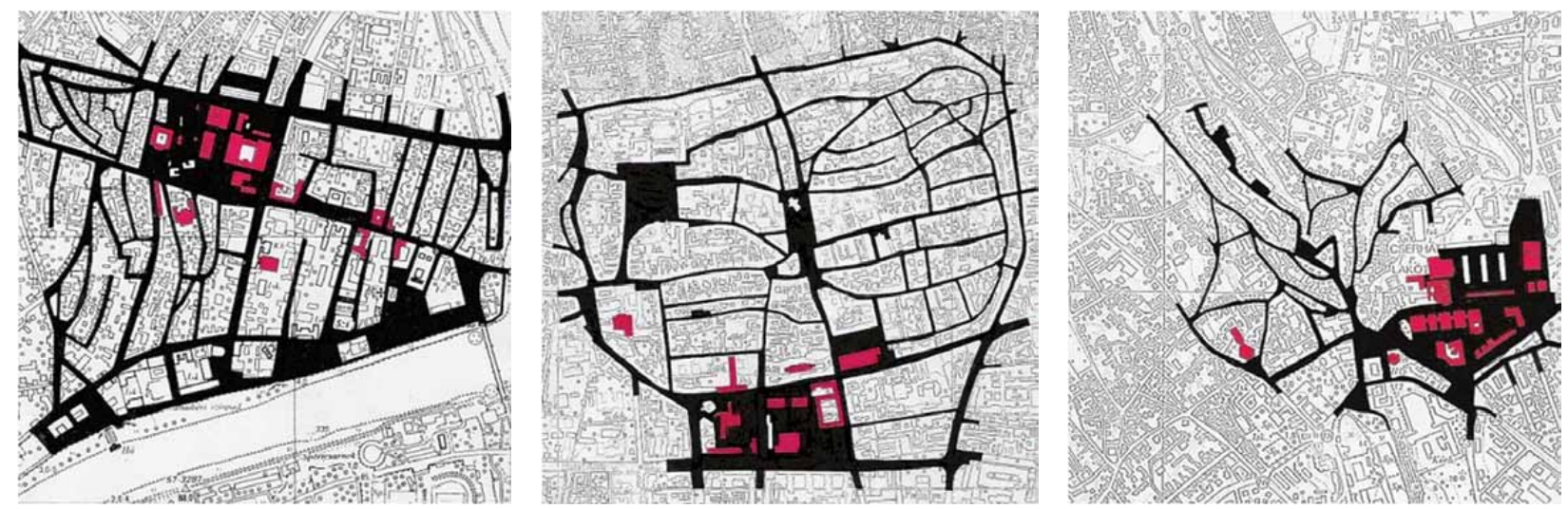

Figs 17-19. Three big Hungarian historical town, that represent new urban fabric, structure and street network organised by new institutial centres without historical context - Szolnok, Pécs, Veszprém (New public buildings of state socialism with red colour) 
framed by shops on the ground floor and by important public buildings, represented for the socialist people the safe welfare of communist market economy and urban life to be thought modern and high quality.

To sum up: while the strongly ideologized former representative squares were assimilated easily through their traditional toolbar, the modern centres characterized by neutral content and strongly marked architectural and urban architectural tools, started life with a serious deficit of identity. The sites of new public building complexes cited into towns or outside it used an individually designed order and inner structure, disregarding original urban block and street patterns of the traditional urban fabric. These island-like sites with their self determined layouts have ruined the fine network of social connections, functional relationships and structural traditions of city centres. This relationship between old and new sites was the conscious intention of planners and the result of the designing practice of the time.

Modernism was not favourable for traditional urban architectural planning values. Due to the ambivalent tradition saving conditions of communism, late Hungarian modernist ideas became provincial, applying a lot of clichés. None of the existing elements of the traditional urban fabric (lot line, street lines, building stock) could change the intentions of ambitious, strong-willed planners. Permeability of urban blocks remained always part of the designing concept, making street functions problematic and confused. As a result, buildings were placed not on the original street lines, but somewhere in the interior of urban blocks.

All cases related these situations like spaces between free standing buildings of the new public building complexes and permeability became important. In the respect of the urban fabric context the island-like complexes were first of all considered as elements that can always be taken out from the urban fabric and installed in another town or district, making the surrounding urban fabric fragmentated.

\section{After change of political system}

\section{Transitional period - change of the political and economical policy}

Before examining the 1980 s, let's have a look at the influence of traditions which determined the contemporary context of our public square types. The country was officially declared to be socialist (Hungarian People's Republic), but Hungarians had serious problems with their socialist identities. Statues of heroes were still there, compulsory holiday celebrations were still going on, but the pathos has already disappeared, everything became oversimplified. All this influenced spatial uses and public space design. The statues of the former idols were surrounded by down-to-earth elements of everyday life, first of all by cars and by parking places.

In the time of communism public space design and street-scape design usually had common features. Their compositions were rarely planned simultaneously, but the relationship between architectural content and form as a long-standing principle was present in architecture during the period of modernism and socialist realism as well. Statues with communist content and high artistic quality were erected often together with water fountains and pools. The time of transition to a new policy and economy in Hungary saw the appearance of a postmodern movement, with city rehabilitations, block openings and living streets with priority of pedestrians over motorists. Red painted wooden benches of the '50s could still be seen on green sites, but under the slogan of humanisation public space renewals and the setting up of pedestrian routes started to use already a new pattern language.

Squares which have lost connection with their architectural environment, were considered as separate elements. In designing historical squares all formerly prohibited planning tools were used without alternatives (candelabrums, cast-iron benches), but there was no proper canon for squares built in communism. A special design language was developed, consciously refusing the historical heritage and giving preference to differences in forms. Although the most important element was dissimilarity, similarity in architecture and in public spaces of different cities seemed to be sometimes stronger than endeavours to elaborate an independent language of forms.

\section{Post-communism}

This above-mentioned process went on in the 1980s and ended when the political and economic regime started to change. Some towns inherited multi-layer public space networks with sub-elements differing in context, size, content, design, behaviour and role.

To make the picture complete, let's have a look at the post-socialist transformation of two city centres.

Although serious financial difficulties hindered the renewal of the main square in Dunaujváros, there were also other serious problems. Even today the square cannot find its role and proper architectural image. It is, however, not because of its form, size or architectural features. These would allow it to fulfill the role of a contemporary, ambitious public space. Its interpretation and rebuilding was delayed so long that city development and use simply 'passed by' and tried to create the city's 
main public square functions spontaneously elsewhere. During the years vehicle traffic became determinant on the former parade routes bounding the square. With the increasing traffic role of roads the original compositional ideas sank into oblivion.

In the centre of the square there used to stand a monumental Lenin statue which was supposed to close visually the space. Most recent plans propose a pool on its place. This idea is reasonable from the point of view of space use, but it doesn't carry the same urban architectural contents as the former statue with a vertical accent.

The communist city centre of Szolnok is full with contemporary urban architectural problems mentioned above. In spite of the functional and architectural changes of centre's buildings the spaces around them cannot regain their original vitality. It's not by chance that in that town too, the development of the former historical market square became the priority of the municipality. Decision was proved right by what happened afterwards; following the recently finished public space renewals it became the most popular public square of the city.

\section{Conclusions}

In spite of these single developments in Dunaujváros one can say that early squares ('The marching pedestrian and his/her speed', or the main square for official functions) built in the '50s could find their urban place even without their political content. The primary reason for this is that the designers used traditional planning tools, which represent their historical urban architectural approaches.

Statues and accentuated elements with a political meaning and marking function were removed without drama. However, their substitution with new ones was risky, although the 'genius loci' worked well for a long time. In the ' 90 s squares were often surrounded by

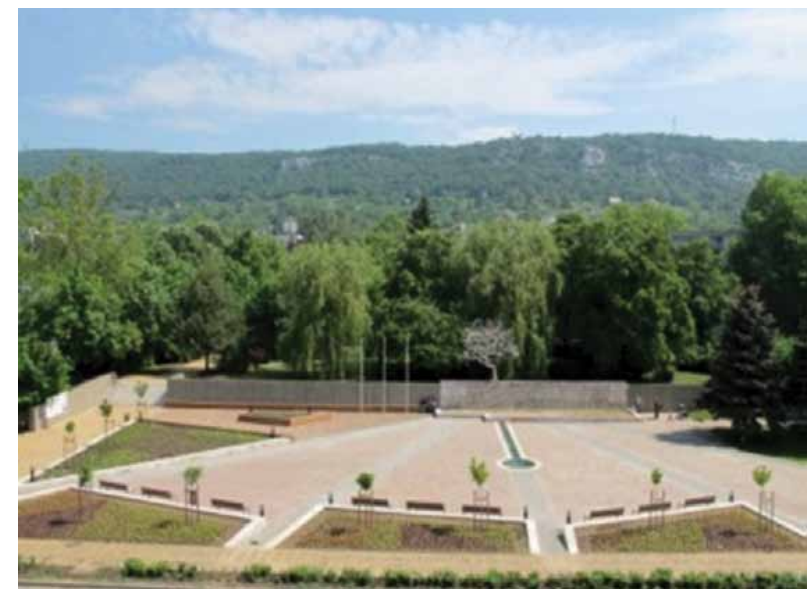

Fig. 20. Tatabánya public building with uncertain functions, but their good potentials (urban context) and architectural values made them capable to survive.

Squares and their networks ('New modernism - new squares for public institutions (1960s) 1970s') like modernist icons have lost their social content. The change of the economic and political system caused crises in socialist services and institutions but the original vitality of squares was based on these functions. The reason while people visited them was not their good accessibility or pleasant microenvironment. Still in their golden age, only the concentrated arrangement of public buildings could ensure the rather vivid life between the buildings. After the economical and political changes access became difficult and squares missed the pleasant microenvironment. The public buildings that have lost their social and economical base, became empty. As a result, spaces around them lost their original meaning and got into a miserable state. The absence of urban context made spaces in between no longer viable.

Lately the importance of public spaces, the need to fill them with new content became a commonsense both for professionals and for laymen. The former social, later individual space use became an independent social issue again. City politicians use the renewal of public spaces for giving gestures in the communication with inhabitants. It serves as a popular and spectacular tool that allows for people's participation without any risk of serious conflicts.

It is not by chance that in the last years the renewal of cities' public spaces, using EU funds, received general attention. There are many competitions and plans for square type situations mentioned earlier.

In our days landscape and general architects are fighting for planning opportunities in public space design. They try to be up to date with current international planning trends (Figs 20, 21). Different plans apply colourful modes of contemporary space

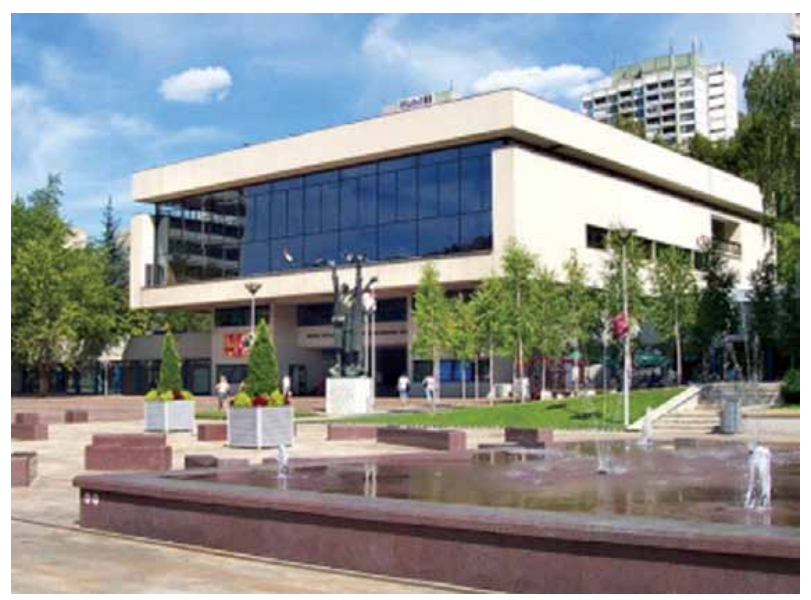

Fig. 21. Salgótarján 
forming, of public space signs and symbols. Plans try to meet all actual space use demands, especially those of young people, which proves their strong social context. They try to meet requirements given by contemporary but often formalistic planning ideas. That we miss are plans that not only refer to the past by their specifications, but actually communicate with it. Mementos, references to antecedents, the use of more elaborated, symbolical tools are out of date. Planners hold 'retro-forms' risky, but sometimes useful, in the renewal of well positioned squares, and sometimes wrong, considering the contrast with existing buildings around. When there is a need to 're-use' or 're-read' buildings in the surroundings, the use of exclusively contemporary planning tools is not suggested. Knowledge and acceptance of the historical antecedents are essential.

Amnesia seems to be an efficient tool in the rehabilitation of squares built in communism. As planners and town-dwellers, we tend to forget the former role of these squares and apply for them all the tools of space architecture available. What is disturbing is that even if there are numerous visual codes (Lefebvre 1991) that can direct us in the actual space-modes, they don't really help to strengthen collective memory and to understand local contexts.

Nowadays, when the rebuilding of old public spaces constitutes a substantial part of urban architectural tasks, it is absolutely necessary to know their history. A precondition to this is that when we redefine public spaces, they should not be simply phisically rebuilt following fashonable trends, but we should create public spaces that are intimately linked to the venue (and its spirit and history), even if we use fashionable designing tools. In this way the renewed squares can find and gain their real urban context and historical continuity. In our days this is the responsibility of the designers.

\section{References}

Barykina, N. 2008. Architecture and spatial practices in postcommunist Minsk: urban space under authoritarian control [online], [cited 28 April 2013]. Spaces of Identity. Available from Internet: https://pi.library.yorku.ca/ojs/index.php/soi/ article/view/18121/16893

Cady, K. A. 2009. National memory and postcommunist Hungary: conflating the "posts"?, Review of Communication 9(1): 12-16. http://dx.doi.org/10.1080/15358590802169496

Clark, K. 2003. Socialist realism and the sacralizing of space, in E. Dobrenko, E. Naiman (Eds.). The landscape of Stalinism: the art and ideology of the Soviet space. Seattle and London: University of Washington Press, 3-19.

Dobrenko, E.; Naiman, E. (Eds.). 2003. The landscape of Stalinism. The art and ideology of Soviet space. Seattle and London: University of Washington Press.

Ferkai, A. 1992. A sztálini építészetről, in P. György, H. Turai (Eds.). A müvészet katonái. Sztálinizmus és kultúra. Bp. Corvina Kiadó, 24-33.
French, R. A.; Hamilton, F. E. I. (Eds). 1979. The Socialist city: spatial structure and urban policy. Chichester: John Wiley \& Sons.

Johnson, A. J.; Glover, T. D. 2013. Understanding urban public space in a leisure context, Leisure Sciences: an Interdisciplinary Journal 35(2): 190-197. http://dx.doi.org/10.1080/01490400.2013.761922

Kissfazekas, K. 2008a. Dilemmas apropos of the role changes of Hungarian town centres after 1945, PP Architecture, BME 2: 67-72.

Kissfazekas, K. 2008b. A magyar városközpontok átalakulása a II, Világháború végétöl a rendszerváltásig 36(1-2): 79-102.

Kissfazekas, K. 2010. Vidéki városközpontok azállamszocializmusban [online], [cited 28 April 2013]. Available from Internet: http:// dokutar.omikk.bme.hu/collections/phd/Epiteszmernoki_ Kar/2011/Kissfazekas_Kornelia/ertekezes.pdf

Kissfazekas, K. 2013. Public building in Hungarian cities under communism (Az államszocialista intézményegyüttesek városi kontextusa). Építés-Építészettudomány, Akadémiai Kiadó (preview 03.14).

Kipnis, J. 1993. Towards a new architecture, AD: Folding and Pliancy. London: Academy Editions.

Kozmlnskl, A. K.; Obloj, K. 1991. Postcommunist reforms from the organizational change perspective, Cybernetics and Systems: an International Journal 22(4): 459-479. http://dx.doi.org/10.1080/01969729108902294

Kwan, M.-P. 2012. The uncertain geographic context problem, Annals of the Association of American Geographers 102(5): 958-968. http://dx.doi.org/10.1080/00045608.2012.687349

Lefebvre, H. 1991. The production of space. London: Basil Blackwell.

McFarlane, C. 2011. On context: assemblage, political economy and structure, City 15(3-4): 375-388. http://dx.doi.org/10.1080/13604813.2011.595111

MacIntyre, S.; Ellaway, A.; Cummins, S. 2002. Place effects on health: how can we conceptualise, operationalise and measure them?, Social Science and Medicine 55(1): 125-139. http://dx.doi.org/10.1016/S0277-9536(01)00214-3

Markevičienè, J. 2012. The spirit of the place - the problem of (re)creating, Journal of Architecture and Urbanism 36(1): 73-81. http://dx.doi.org/10.3846/20297955.2012.679789

Prakfalvi, E. 2002. A 20. század második felének építészete, in L. Beke, E. Gábor, E. Prakfalvi, J. Sisa, J. Szabó (Eds.). Magyar müvészet 1800-tól napjainkig. Budapest: Corvina, 255-301.

Prakfalvi, E.; Szücs, Gy. 2010. A szocreál Magyarországon. Corvina.

Shields, R. 1986. Henri Lefebvre, the question of space and the postmodern hypothesis. MA Thesis, Carleton University Ottawa.

Simmel, G. 2005. The metropolis and mental life, in Urban sociology. Routledge.

Smith, M. 1996. The Socialist City, in G. Andrusz, M. Harloe, I. Szelenyi (Eds.). Cities after socialism: urban and regional change and conflict in post-socialist societies. Cambridge, MA: Blackwell Publishers, 70-99.

Soja, E. 1985. The spatiality of social life: towards a transformative retheorization, in D. Gregory, J. Urry (Eds.). Social relations and spatial structures. London: Macmillan.

Szirmai, V. 1988. 'Csinált’ városok. Magvető - Gyorsuló idő.

Szirmai, V. 1998: 'Socialist' Cities (New Towns) in the Postsocialist Era, in Gy. Enyedi (Ed.). Social change and urban restructuring in Central Europe. Akadémiai Kiadó, Budapest, 169-189. 


\section{KORNELIA KISSFAZEKAS}

Ph.D, architect, urban planner. Department of Urban Planning and Design, Faculty of Architecture, Budapest University of Technology and Economics, Müegyetem rkp. 3. K. II/93, 1111 Budapest, Hungary.

E-mails: kissfazekas@gmail.com; kissfazekas@urb.bme.hu

She gained more than 20 years of work experience in an office of urban architecture. Her professional activity covers wide scale of urban planning and design. Paralel with her designing work she begun to teach as a part-time lecturer at the Department of Urban Planning and Design of the Technical University of Budapest. She is consultant of several practical courses and lecturer in Hungarian urban history. Her research work and publications focus mainly on this subject.

Research interests: Hungarian towns in the 20th century, Urban Planning Theory/Urban Design during the (post)communist period; urban context; urban morphology; public space design. 